\title{
Mechanical behavior of pumpkin fruits subjected to compression during maturation ${ }^{1}$
}

\author{
Acácio Figueiredo $\mathrm{Neto}^{2}$, Francisco de Assis Cardoso Almeida ${ }^{3}$, \\ Nelson Cárdenas Olivier ${ }^{2}$, Alan Christie Silva Dantas ${ }^{2}$, Marcos Antonio Silva Irmão ${ }^{2}$
}

\begin{abstract}
RESUMO
Comportamento mecânico de frutos de abóbora submetidos a compressão durante a maturação

Durante as operações de manuseio, podem ocorrer vários problemas que reduzem a qualidade das hortaliças. As injúrias mecânicas são a causa principal de perdas pós-colheita, para as abóboras, e podem ocorrer em qualquer ponto da cadeia de produção. Objetivou-se, com o presente trabalho, estudar o comportamento de frutos de abóbora, durante os estádios de maturação, nos valores da força máxima de compressão para deformações fixas, e determinar o módulo proporcional de deformidade desta hortaliça submetida a compressão, em posição de repouso. Os frutos foram colhidos aos 15, 30, 40, 50 e 60 dias após a fecundação e comprimidos uniaxicialmente, entre duas placas paralelas. A partir dos resultados obtidos, concluiu-se que tanto a força de compressão necessária, como o módulo proporcional de deformidade, aumentaram com a maturação, atingindo força máxima de $1.778 \mathrm{~N}$ e módulo de deformidade máxima de $164 \mathrm{MPa}$, após 30 dias. Após este período, tanto os valores da força máxima, quanto os valores do módulo, decresceram, chegando a $1.514,8 \mathrm{~N}$ de força máxima e módulo de 132,09 MPa, após 60 dias de maturação. Com o aumento do tempo de maturação, ocorreu aumento na rigidez dos frutos, com consequente aumento na carga máxima para atingir maiores deformações. O tempo ideal para colheita e transporte dos frutos da abóbora 'Jacarezinho' foi de 30 a 40 dias após a antese.
\end{abstract}

PALAVRAS-CHAVE: Propriedades reológicas; danos mecânicos; módulo de deformidade.

\section{INTRODUCTION}

The origins of pumpkin lie in the central region of Mexico. It is a tropical species, whose production is favored by high temperatures. Belonging to the Cucurbitaceae family and the Cucurbita genus (Sasaki et al. 2006), it presents varied shapes and sizes, and can be harvested at different maturation stages, even before reaching its definite size.

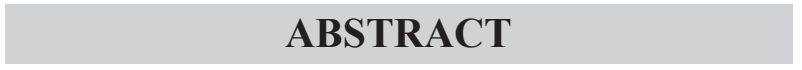

During handling operations, many problems that reduce the quality of vegetables may occur. Mechanical injuries are the leading cause of postharvest losses for the pumpkin, and can take place at any point of the production chain. This study aimed at evaluating the pumpkin fruits behavior, during their ripening stages, on the values of maximum compression force for fixed deformations, and determining the proportional deformability modulus of the fruits under compression at the repose position. Fruits were harvested at 15, 30, 40, 50 and 60 days after flowering and uniaxially compressed between two parallel plates. The results allowed to conclude that both the required compression force and the proportional deformability modulus increased during the maturation course, reaching a maximum force of $1,778 \mathrm{~N}$ and a maximum deformation modulus of $164 \mathrm{MPa}$, after 30 days. After this period, both the maximum force and the modulus values decreased, reaching 1,514.8 $\mathrm{N}$ of maximum force and a modulus of $132.09 \mathrm{MPa}$, after 60 days of ripening. Over the course of a longer maturation time, the fruit firmness increased, therefore requiring an increase in the maximum load to achieve greater deformation. The ideal period for harvest and transport of 'Jacarezinho' pumpkin fruits was set from 30 to 40 days after anthesis.

KEY-WORDS: Rheological properties; mechanical damage; deformability modulus.

However, for industrial use, the fruit must be harvested when already ripe, or when the stem is dry and the skin hard (Silva 2009).

Its fruit often goes through a series of mechanical injuries, from the moment they are harvested until consumption, and, depending on their susceptibility, the damage caused may compromise the end quality, reaching losses as great as $25 \%$ of the overall production, an amount that justifies a greater

1. Article received in Dec./2012 and accepted for publication in Jul./2013 (Registration number: PAT 21407)

2. Universidade Federal do Vale do São Francisco (Univasf), Departamento de Engenharia, Juazeiro, BA, Brasil. E-mails: acacio.figueiredo@univasf.edu.br,nolivierc@gmail.com, alan.dantas@univasf.edu.br,marcosunivasf2012@gmail.com. 3. Universidade Federal de Campina Grande (UFCG), Departamento de Engenharia Agrícola, Campina Grande, PB, Brasil. 
investment in technology and equipment, rather than an increase in the production area (Castricine et al. 2012).

The study of mechanical characteristics of agricultural products is important, since equipments have to be developed in order to obtain a maximum efficiency, without compromising the end quality of the product. Agricultural products may suffer cracks and fractures, if the strains they are subjected to exceed their resistance (Resende et al. 2007).

In general, fruit mechanical damage may cause translucent aqueous lesions, precocious softening, rupture of the epidermis (Durigan \& Mattiuz 2007) or physiological, chemical or bio-chemical changes in color, scent, taste and texture, as well as a consequent acceleration of the deterioration process (Lee et al. 2005).

Postharvest losses due to mechanical damage caused by mechanical tension, such as compression, impact or cuts, are more frequent in rural properties where little technology is used and financial resources are scarce. Transportation within the rural property is a crucial moment for the aspect of the product, for it is during its transport and heaping that most of the little impacts, compressions and cuts occur, many of which will be noticeable only after maturation (Rocha et al. 2011).

Among the diverse mechanical properties, the deformability modulus allows comparisons of many materials, concerning their relative resistance. According to Couto et al. (2002), when studying the mechanical behavior of a material, the deformability modulus is more significant than the elasticity modulus, considering that when a product is compressed, it is the total deformation that has practical applicability.

The deformability modulus is a function of the Poisson's ratio that assumes constant values for each material, being its value for pumpkins unknown. In the absence of this value, Batista et al. (2003) used another variable, proportional to the deformability modulus, denominated proportional deformability modulus.

Several factors affect the mechanical properties of agricultural products, such as drying temperature, water content, kind of force and grain area where this kind of force is applied (Mohsenin 1986, Li et al. 1989, Resende et al. 2007).

When determining the proportional deformability modulus for coffee fruits, in the maturity stages denominated "green", "greenish" and "cherry", under different moisture contents, Couto et al. (2002) concluded that the proportional deformability modulus decreased as the fruits deformation increased.

Batista et at. (2003) verified that the proportional deformability modulus for coffee fruits subjected to drying temperatures of $40^{\circ} \mathrm{C}, 50^{\circ} \mathrm{C}$ and $60^{\circ} \mathrm{C}$, with moisture ranging from 0.14 to 1.50 (d.b.), in all three maturity stages, reached values between $2.0 \times 10^{7} \mathrm{~Pa}$ and $18.0 \times 10^{7} \mathrm{~Pa}$ for cherry coffee fruits, $5.0 \times 10^{7} \mathrm{~Pa}$ and $40.0 \times 10^{7} \mathrm{~Pa}$ for green fruits, and $1.0 \times 10^{7} \mathrm{~Pa}$ and $50.0 \times 10^{7} \mathrm{~Pa}$ for greenish fruits.

Gupta \& Das (2000) evaluated the mechanical behavior of sunflower seeds and verified that with an increase of moisture content from $3.8 \%$ to $16.6 \%$ (w.b.), the rupture force of the product was reduced and its deformation increased.

Tascón et al. (2002), evaluating the influence of an attack of coffee berry borers on the firmness of cherry fruits and parchment coffee (dry and wet) subjected to compression tests, observed that the cherry fruits did not show a significant difference in firmness for healthy and affected fruits. For the parchment coffee, however, the firmness of healthy beans was statistically superior to the one presented by affected beans, evidencing the influence of the insect attack on the mechanical properties of coffee fruits.

Postharvest operations very often cause impacts and compressions that result in crushes in the fruit pulp, which consequently lead to the deterioration of the agricultural product. The worst kinds of damage are caused mainly during the handling process for transportation by trucks, in bulk or in boxes (Yam-Tzec et al. 2011).

Considering those aspects and also the scarcity of theoretical information on the mechanical properties of pumpkin fruits, this study aimed at evaluating the influence of the maturity stage on the values of maximum compression force for fixed deformations, as well as determining the proportional deformability modulus for pumpkin fruits subjected to compression at the repose position.

\section{MATERIAL AND METHODS}

The present experiment was carried out at the Mechanical Engineering Department of the Universidade Federal do Vale do São Francisco, in Juazeiro, Bahia State, Brazil. 
'Jacarezinho' pumpkin (Curcubita moschata Duch.) fruits were manually harvested at 15, 30, 40, 50 and 60 days after flowering. Five fruits presenting uniform size and homogeneous staining without damage were taken to the laboratory for compression. Diverse maturation stages were obtained by harvesting fruits at each maturation stage, at the experimental field of the Universidade do Estado da Bahia, in Juazeiro, Bahia State, Brazil, where cultivation was carried out from December 2010 to March 2011.

Fruits were individually submitted to experimental compression tests, by using a universal testing machine (model DL-10000 Emic Ltda.), with a load cell of $100 \mathrm{kN}$, where they were subjected to uniaxial compression, between two parallel plates, at the repose position (Figure 1), and force application rate of $0.005 \mathrm{~m} \mathrm{~s}^{-1}$. Five pumpkin fruits were used for each maturation stage and the compression tests were concluded when the fruits ruptured.

According to ASAE (2003), the apparent deformability modulus of a convex body can be determined as it follows:

$$
E=\frac{0.531 \cdot F \cdot(1-\mu)^{2}}{D^{3 / 2}} \cdot\left[2 \cdot\left(\frac{1}{r}+\frac{1}{R}\right)^{1 / 3}\right]^{3 / 2}
$$

where $\mathrm{E}=$ deformability modulus $(\mathrm{Pa}) ; \mathrm{F}=$ compression force $(\mathrm{N})$; $\mathrm{D}=$ total deformation (elastic and plastic) of the body in the contact points of the upper and lower plates $(\mathrm{m}) ; \mathrm{m}=$ Poisson's ratio, according to Hernández et al. (2002); R, r = radius of curvature on the contact point (m).

The proportional deformability modulus of pumpkins $\left(E_{p}\right)$ was determined for deformations of

(a)

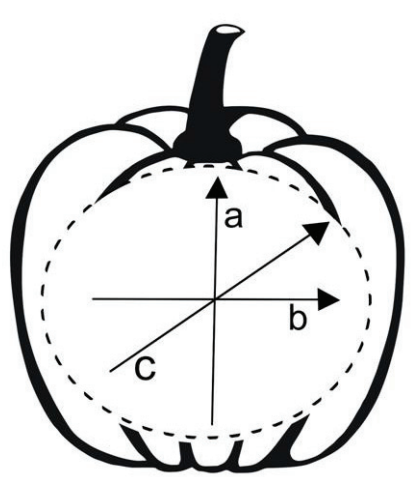

$2.5 \times 10^{-3} \mathrm{~m}, 5.0 \times 10^{-3} \mathrm{~m}, 7.5 \times 10^{-3} \mathrm{~m}$ and $10 \times 10^{-3} \mathrm{~m}$, as it follows:

$$
\mathrm{Ep}=\frac{\mathrm{E}}{(1-\mu)^{2}}=\frac{0.531 \cdot \mathrm{F}}{\mathrm{D}^{3 / 2}} \cdot\left[2 \cdot\left(\frac{1}{\mathrm{r}}+\frac{1}{\mathrm{R}}\right)^{1 / 3}\right]^{3 / 2}
$$

where $\mathrm{Ep}=$ proportional deformability modulus $(\mathrm{Pa})$.

For each maturation stage, values for the fruit radius of curvature ( $\mathrm{r}$ and $\mathrm{R}$ ) in the contact points were obtained through adjustments to the body circumference curvatures, measured with the aid of a caliper, according to the coordinate plane position rest, during the compression test (Figure 1).

The data for the maximum compression force and for the proportional deformability modulus were represented in accordance with the maturation stage.

An optical microscope (model B-Mic 1000) was used to evaluate the morphological chamber on fine slices of pumpkin pulp. Methylene blue was used to improve the contrast of the cell membrane.

The data analysis was carried out by using the SPSS software (Maroco 2003), considering a probability of error (p) lower than or equal to $5 \%$. Regression tests were applied for each deformation force, according to each fruit maturation stage, with eleven curve estimations being evaluated and the one with the highest determination coefficient $\left(\mathrm{R}^{2}\right)$ being selected. The lowest probability of error was pointed out by the variance analysis (Anova) - test $F$, with results being graphically expressed along with the respective equations generated.

In order to better investigate the variance for each fruit maturation stage, Anova was applied, while the Welch's Robust test was used for evaluating data without homogeneity among samples. Thereafter,

(b)

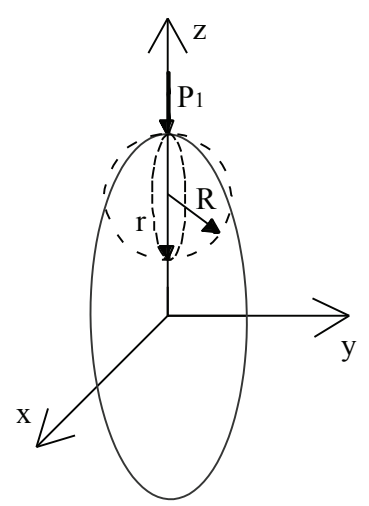

Figure 1. Radius of curvature of the pumpkin fruit on the region of contact between the product and the compression plate at the repose position, product of dimensions (a) and direction of the compression force (b) on the product (Juazeiro, BA, 2011). 
means were compared with the aid of the Tukey test and values were obtained for standard deviation $( \pm \mathrm{SD})$, coefficient of variation $(\%)$, and confidence intervals (95\%).

\section{RESULTS AND DISCUSSION}

Table 1 shows mean values for radius of curvature of pumpkin fruits ('Jacarezinho' cultivar) used to determine the proportional deformability modulus. It can be verified that the radii of curvature increased during the maturation of the product.

Figure 2 shows the behavior of force (2a), deformability modulus (2b) and deformation (2c), in the course of the maturation stages. Both the force and the deformability modulus (Ep) increased along with the progressing ripening, reaching a maximum force of $1,778 \mathrm{~N}$ and a maximum modulus of $164 \mathrm{MPa}$, at 30 days. After this period, the values for maximum force, as well as the Ep values, decreased, reaching 1,514.8 $\mathrm{N}$ of maximum force and $132.09 \mathrm{MPa}$ of Ep, at 60 days. The fruits pulp dried and reached a dark orange color with the increase of the ripening time.

Figure 3 shows the force and deformation curves for fruits sampled at different maturation stages. After 15 days of maturation, fruits presented maximum deformation for minimum values of applied force. Along with the maturation process, fruits tended to deform less than when subjected to higher levels of applied force. After 40 days of maturation, the pumpkin fruits reached a maximum force of $1,900 \mathrm{~N}$, for a deformation of $19.24 \mathrm{~mm}$. Longer maturation periods resulted in the reduction of maximum deformation, evincing an increase in the fruit firmness, along the maturation course.

Due to the fact that the fruits presented different maximum deformation values until rupture, the relation between maximum force and maximum

Table 1. Mean values for radius of curvature of pumpkin fruits $\left(\mathrm{x} 10^{-3} \mathrm{~m}\right)$, for each maturation stage (Juazeiro, BA, 2011).

\begin{tabular}{cccccc}
\hline \multirow{2}{*}{$\begin{array}{c}\text { Radius of curvature } \\
(\mathrm{mm})\end{array}$} & \multicolumn{5}{c}{$\begin{array}{c}\text { Maturation stage } \\
\text { (days after anthesis) }\end{array}$} \\
\cline { 2 - 6 } & 15 & 30 & 40 & 50 & 60 \\
\hline $\mathrm{r}$ & 49.90 & 56.00 & 57.75 & 58.75 & 61.25 \\
Standard deviation (SD) & 0.050 & 0.051 & 0.057 & 0.056 & 0.057 \\
$\mathrm{R}$ & 64.50 & 81.25 & 80.20 & 86.95 & 93.98 \\
Standard deviation (SD) & 0.057 & 0.050 & 0.050 & 0.570 & 0.057 \\
\hline
\end{tabular}
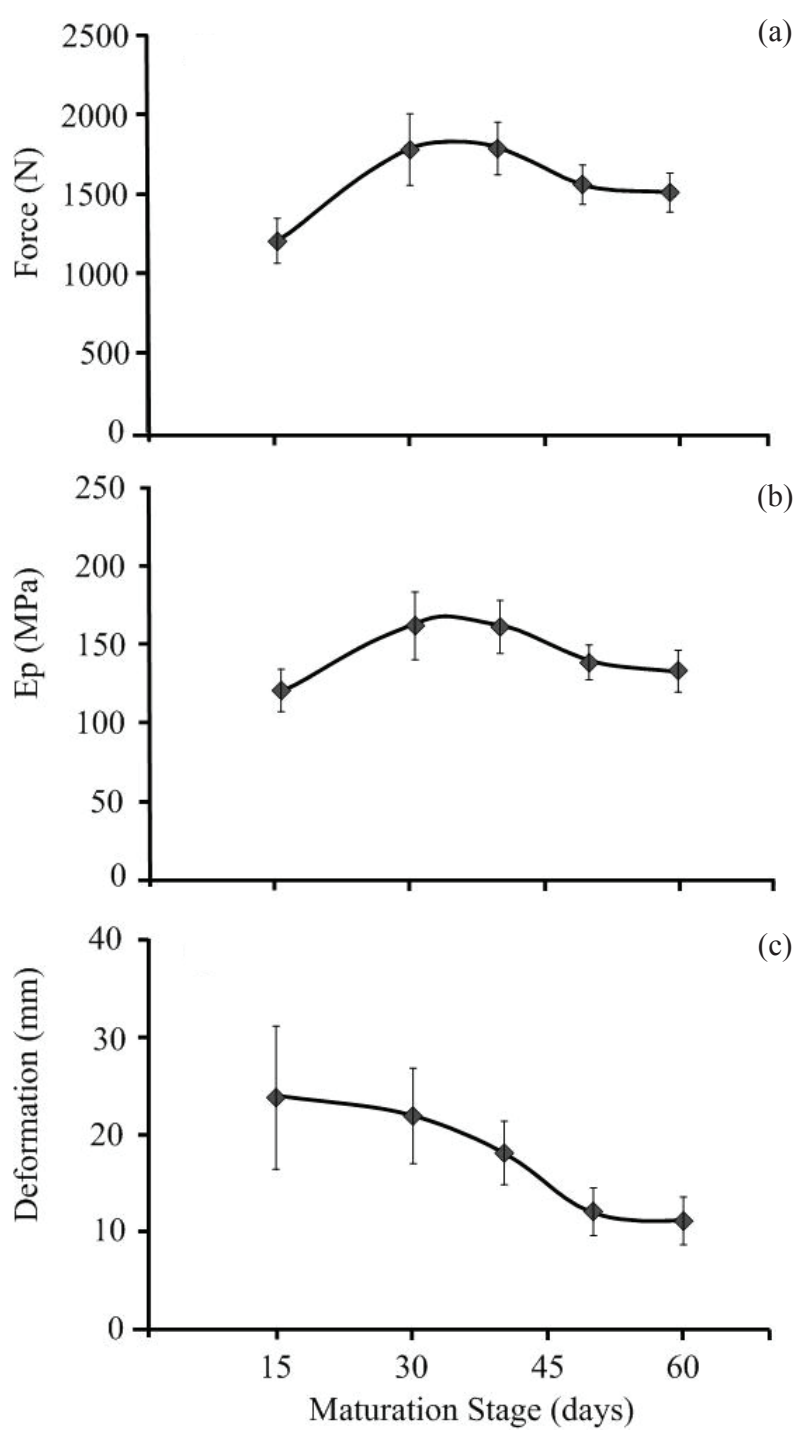

Figure 2. Mean values for maximum compression force (a), proportional deformability modulus (b) and maximum deformation until rupture (c), according to the maturation stage (Juazeiro, BA, 2011).

deformation was analyzed for specific deformity values varying from $2.5 \mathrm{~mm}$ to $10.0 \mathrm{~mm}$ (Figure 4). Thus, it was possible to observe that the load required to promote a deformation of $2.5 \mathrm{~mm}$ does not depend on the maturation stage. To reach higher deformation levels, however, the necessary load depends on the maturation time, since a load of $587.44 \mathrm{~N}$ was needed to obtain a deformation of $10.0 \mathrm{~mm}$ at 15 days of maturation, whereas $1,253.9 \mathrm{~N}$ was required at 60 days of maturation. This result shows that, along the maturation course, the fruit firmness increases according to the consequent increase in the maximum load to obtain greater deformation. 


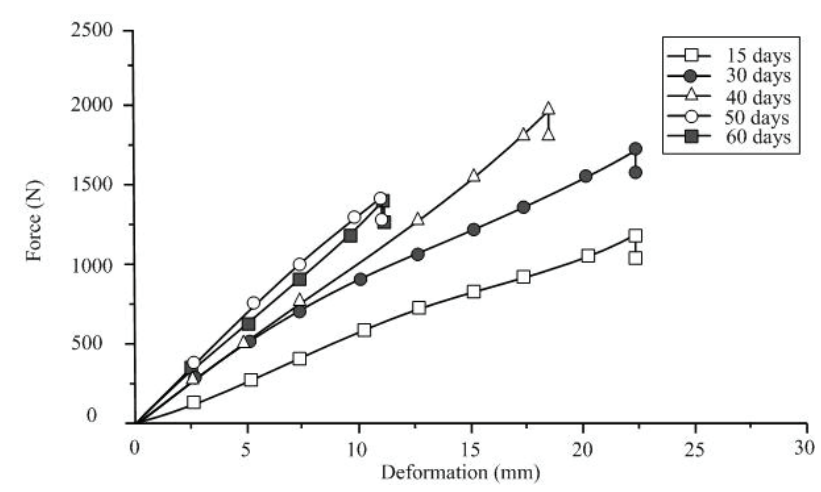

Figure 3. Force and deformation curves for fruits harvested after 15, 30, 40, 50 and 60 days (Juazeiro, BA, 2011).

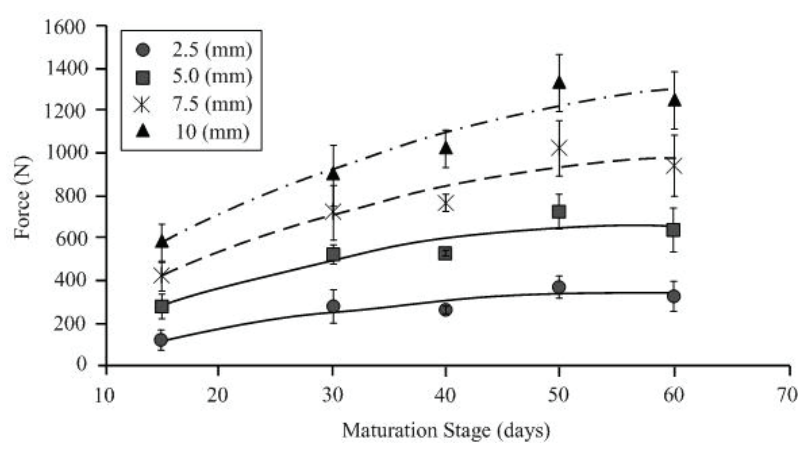

Figure 4. Maximum force for four specific deformity values, during the maturation stages (Juazeiro, BA, 2011).

The mechanical properties of cellular food materials, such as vegetables and fruits, have been associated to the different structural levels of the material (Ferrari et al. 2011). At the microstructural level, what can be pointed out as relevant for texture is the structure and chemical composition of the polymers that constitute the cell wall, the cell wall thickness and the cell turgor pressure, as well as the mechanical resistance and type of adhesion among cells (Mayor et al. 2007).

Higher structural levels can be observed in the tissue structure, for instance, cell orientation, number of intercellular pores and different types of tissue comprising the vegetable product.

Changes in the mechanical properties are caused by moisture loss, so that the mechanical resistance tends to be lower for apple and banana (Krokida et al. 2000). For grains, however, an increase in the mechanical properties has been reported for reductions in the moisture content (Ribeiro et al. 2007). An increase in firmness, on the other hand, has been reported for both fruits and grains (Lewicki \& Jakubczyk 2004, Telis et al. 2005).

According to Gonçalves et al. (2005), the total moisture content decreases in the course of the ripening process, evincing that the pumpkin pulp (Cucurbita moschata and Cucurbita maxima) becomes dryer. This reduction in moisture content tends to cause an increase in firmness, as fruits tend to lose flexibility, when they lose water.

The statistical analysis and consequent reliability of the results can be observed in Figures 5 and 6 , respectively related to the maximum force and the proportional deformability modulus, which present a sigmoidal behavior.

The compression force required to deform a fruit in $2.5 \mathrm{~mm}, 5.0 \mathrm{~mm}, 7.5 \mathrm{~mm}$ and $10.0 \mathrm{~mm}$ increased during the course of the maturation stages, in agreement with Henry et al. (2000), who studied the compressive strength of nine soybean varieties, harvested at two different periods, and observed that the maximum tangent and secant modules decreased with an increase in moisture.

For the highest moisture content, or during the initial maturation stage, the 'Jacarezinho' pumpkin fruits offered little compressive strength, which increased proportionally to the reduction in moisture content, i.e., during the maturation course. This tendency was probably due to the gradual change in the integrity of the cellular matrix, with the reduction in moisture content (Gupta \& Das 2000).

The maximum load sustained by pumpkin fruits, at 40 days after anthesis, was $1,800 \mathrm{~N}$ (approximately $184.0 \mathrm{~kg}$ ). If we consider $1.5 \mathrm{~kg}$ the average weight for this fruit, it can be observed that a heap of 122 fruits would be sufficient to cause the rupture of the fruits in the lowermost layer. However, it has to be evaluated what maximum load would be necessary to cause irreversible damage related to impact.

Another factor to be observed is that the pumpkin pulp has a cellular honeycomb structure formed by interconnected pore walls (Figure 7). Gonçalves et al. (2005) showed that, during the maturation course, the cells grow and the cell wall thickness decreases, being the main factors to cause losses in the mechanical properties of biological materials (Gibson \& Ashby 1997).

According to Pla et al. (2009), who studied the characteristics of pumpkin pulp under compression and the application of iron in food supplements, no changes 
(a)

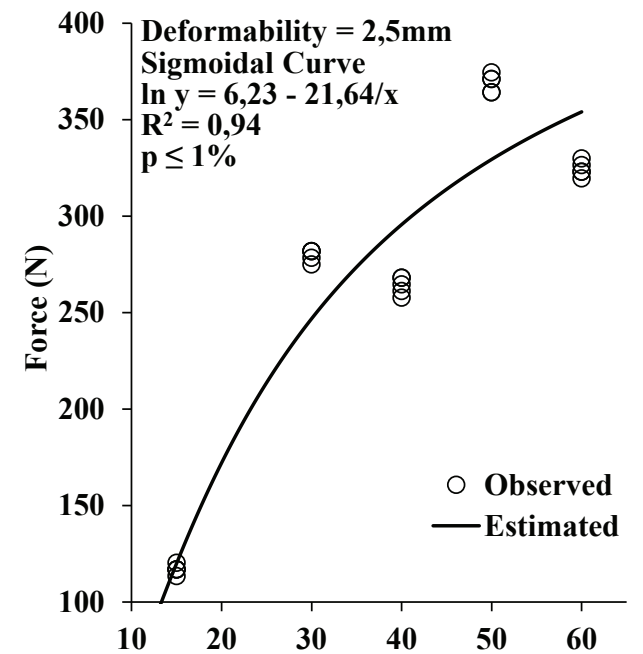

(c)

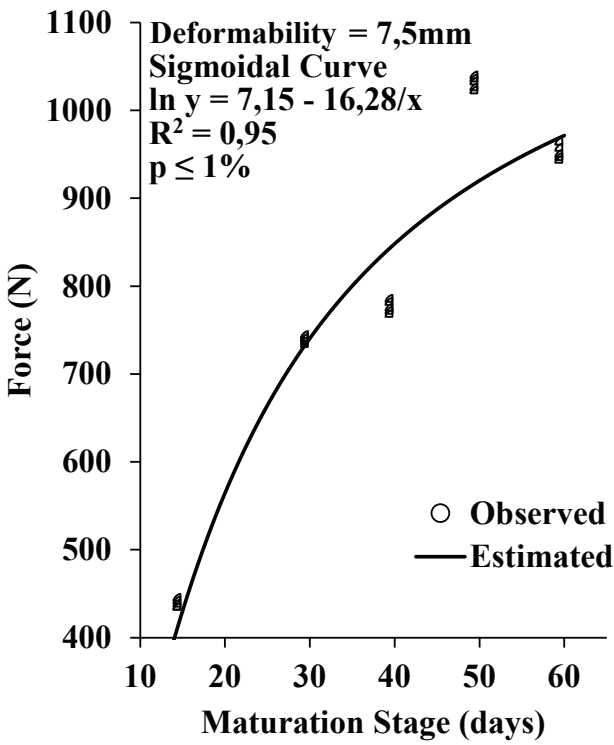

(b)

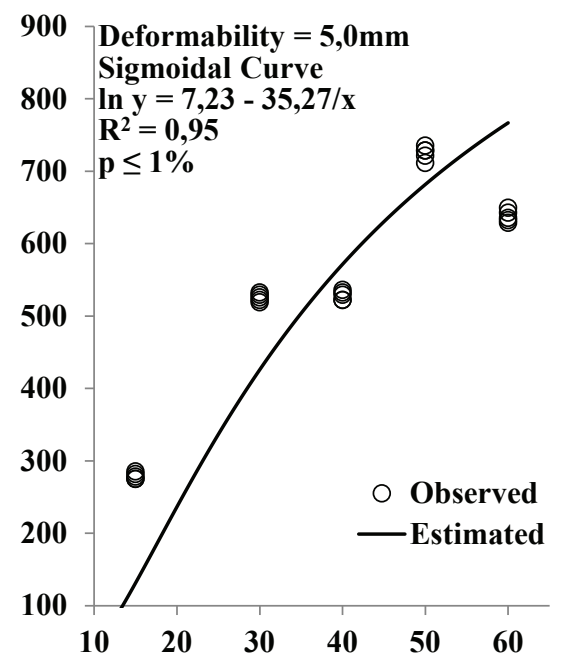

(d)

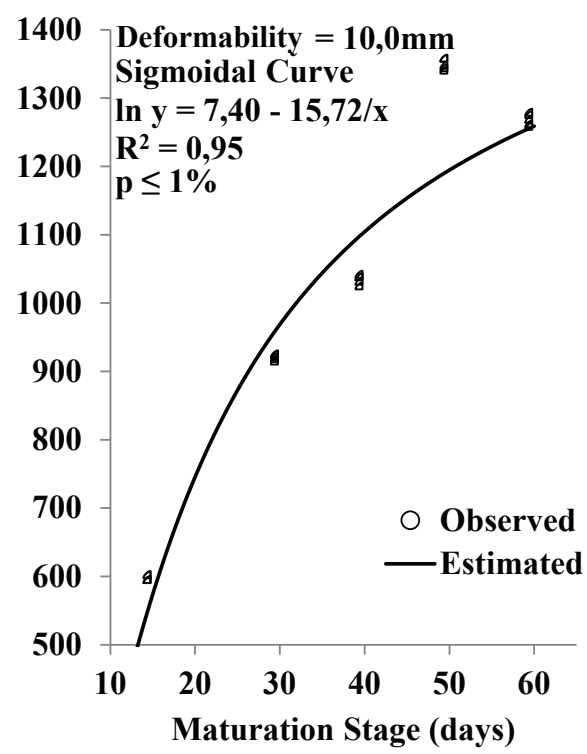

Figure 5. Maximum force sustained by 'Jacarezinho' pumpkin fruits for deformities of $2.5 \mathrm{~mm}(\mathrm{a}), 5.0 \mathrm{~mm}(\mathrm{~b}), 7.5 \mathrm{~mm}(\mathrm{c})$ and $10.0 \mathrm{~mm}$ (d), during five maturation stages (Juazeiro, BA, 2011).

in firmness were observed during storage. Divergently, the present investigation analyzed the same mechanical property, during the five studied maturation stages, and verified an increase in firmness.

Certain geometrical aspects of the cell structure are crucial for the comprehension of mechanical properties (Figure 7). Cellular materials are often mechanically efficient: the honeycomb microstructure of wood, for instance, offers an exceptionally high performance in resisting bending and deformation (Gibson \& Ashby 1997).

Together with the increase in firmness, an increase in brittleness was also observed in the fruits that began to absorb less strain before rupture (Figure 3). According to Hawthorne (1990), during maturation in the field, the dry matter content of the product increases to a maximum, and then decreases, as the level of sucrose tends to be stabilized, or even increase, during storage.

During loading, the area under the stress-strain curve is the strain energy per unit volume absorbed by the material. Conversely, the area under the unloading curve is the energy released by the product (Roylance 2000).

The fact that the fruits appear physiologically developed, as observed by Santos \& Chitarra 
(a)

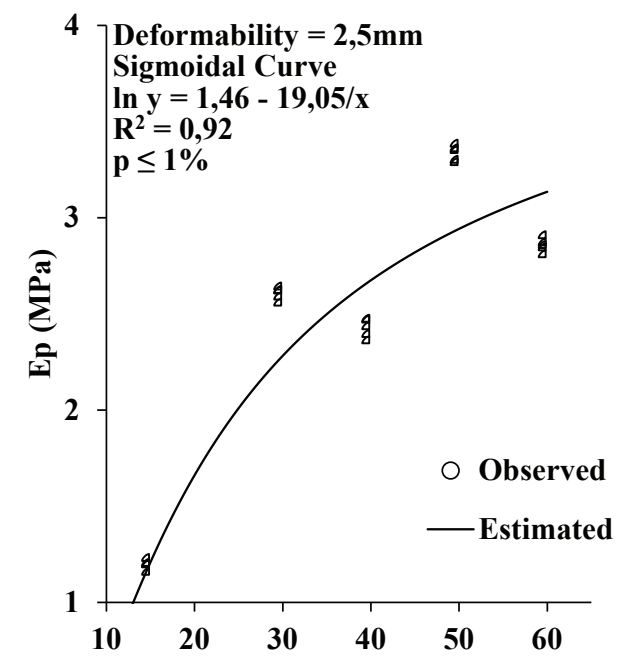

(c)

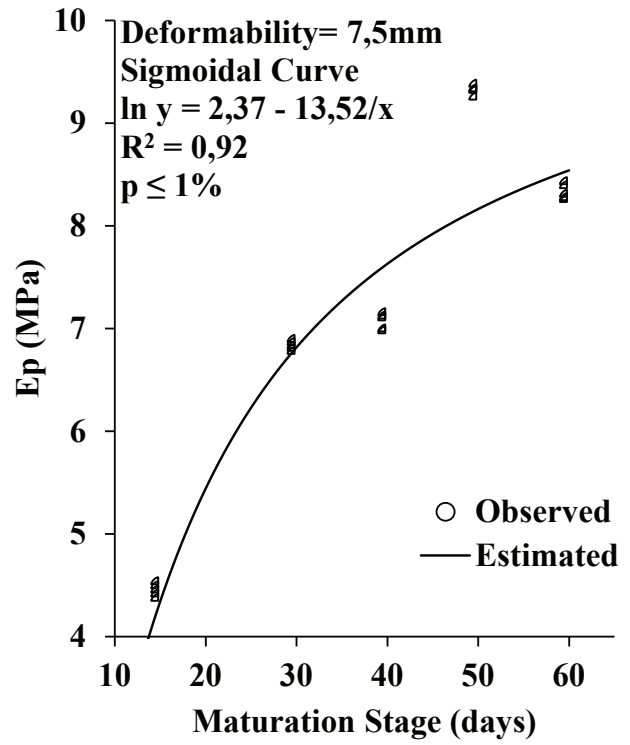

(b)

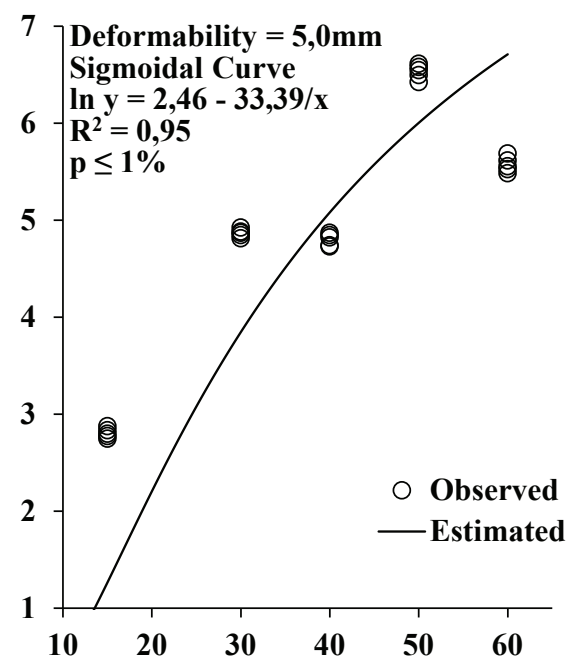

(d)

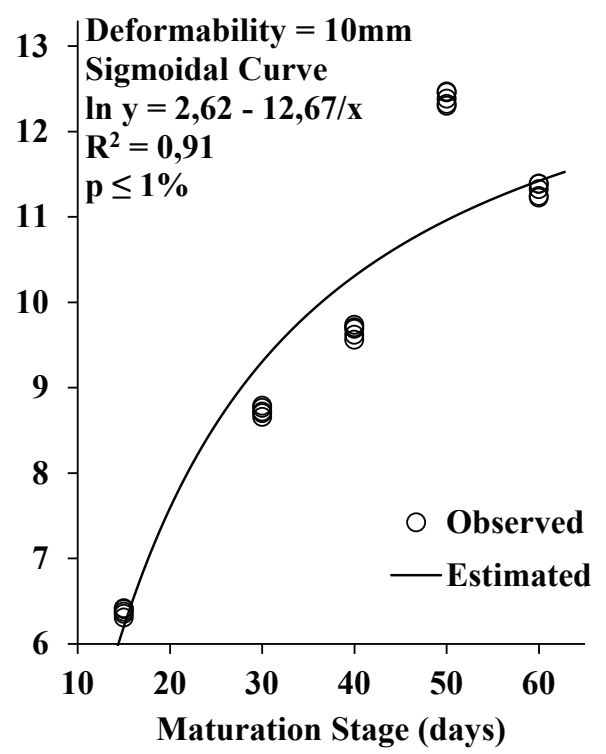

Figure 6. Data related to the proportional deformability modulus sustained by 'Jacarezinho' pumpkin fruits for deformities of $2.5 \mathrm{~mm}$ (a), $5.0 \mathrm{~mm}$ (b), $7.5 \mathrm{~mm}$ (c) and $10.0 \mathrm{~mm}$ (d), during five maturation stages (Juazeiro, BA, 2011).

(a)

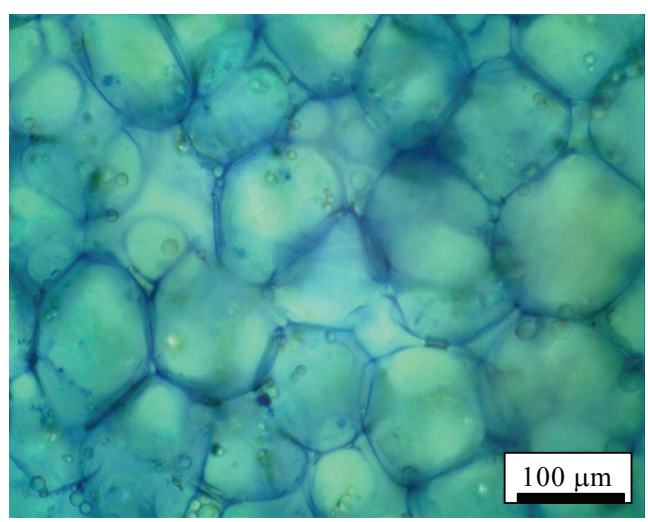

(b)

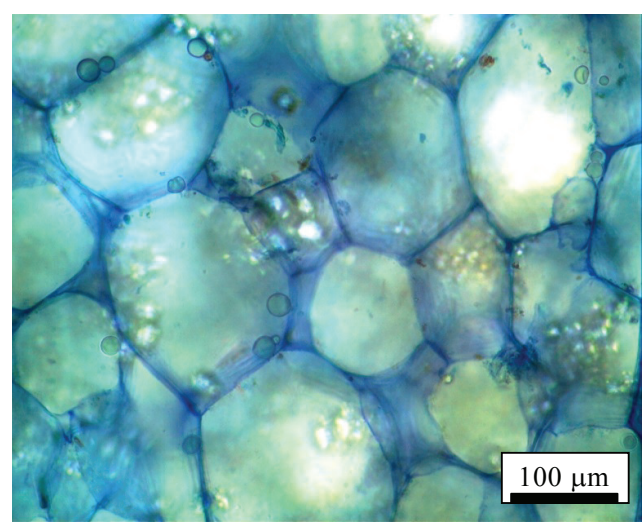

Figure 7. Microstructural features of pumpkin fruits at 15 (a) and 60 (b) days after anthesis (Juazeiro, BA, 2011). 
(1998), might be due to a greater integrity of the cell wall, which contributes to a delay in the effects of harvest conditions on the activity of some enzymes responsible for fruit ripening (Neves 2009).

As all climacteric fruits, the 'Jacarezinho' pumpkin is perishable and susceptible to mechanical damage during late harvest, what represents an obstacle for commercialization and quality maintenance. The harvest of green fruits usually starts two months after germination, while the fruit is considered mature four months after germination.

\section{CONCLUSIONS}

1. The mechanical property of pumpkin fruits increased along their maturation course, reaching a maximum value at 30 days after anthesis.

2. With the maturation stages progress, an increase in firmness, which promoted an increase in the deformability modulus, was observed.

3 . For the four deformations studied during the fruits maturation, values between $116.8 \mathrm{~N}$ and $1,254.9 \mathrm{~N}$ were obtained.

4. The ideal period observed for harvest and transport of 'Jacarezinho' pumpkin fruits was from 30 to 40 days after anthesis.

5. For the diverse evaluated maturation stages, the sigmoidal model appropriately represented the compressive strength of pumpkin fruits.

\section{REFERENCES}

AMERICAN SOCIETY OF AGRICULTURAL ENGINEERS (ASAE). Agricultural engineers yearbook of standards. San Joseph: ASAE, 2003.

BATISTA, C. S. et al. Efeito da temperatura do ar de secagem, do teor de umidade e do estádio de maturação no módulo de deformidade de frutos de café (Coffea arabica L.). Revista Brasileira de Armazenamento, Viçosa, v. esp., n. 6, p. 42-53, 2003.

CASTRICINI, A.; CONEGLIAN, R. C. C.; DELIZA, R. Starch edible coating of papaya: effect on sensory characteristics. Ciência e Tecnologia de Alimentos, Campinas, v. 32, n. 1, p. 84-92, 2012.

COUTO, S. A. et al. Comportamento mecânico de frutos de café: módulo de deformidade. Revista Brasileira de Engenharia Agrícola e Ambiental, Campina Grande, v. 6, n. 2, p. 285-294, 2002.

DURIGAN, M. F. B.; MATTIUZ, B. H. Injúrias mecânicas e seus efeitos na qualidade de melancias armazenadas em condições ambiente. Horticultura Brasileira, Brasília, DF, v. 25, n. 2, p. 296-300, 2007.

FERRARI, C. C. et al. Propriedades mecânicas e estrutura celular de melão desidratado osmoticamente em soluções de sacarose ou maltose, com adição de lactato de cálcio. Ciência e Agrotecnologia, Lavras, v. 55, n. 2, p. 765-773, 2011.

GIBSON, L. J.; ASHBY, M. F. Cellular solids: structure and properties. 2. ed. Cambridge: Ashby, 1997.

GONÇALVES, E. M. et al. Influence of maturity stage on texture, pectin composition and microstructure of pumpkin. In: MERCOSUR CONGRESS ON PROCESS SYSTEMS ENGINEERING, 4., 2005, Rio de Janeiro. Anais... Rio de Janeiro: Empromer, 2005. 1 CD-ROM.

GUPTA, R. K.; DAS, S. K. Fracture resistance of sunflower seed and kernel to compressive loading. Journal of Food Engineering, Dublin, v. 46, n. 2, p. 1-8, 2000.

HAWTHORNE, B. T. Age of fruit at harvest influences incidence of fungal storage rots on fruit of Cucurbita maxima D. hybrid 'Delica'. New Zealand Journal of Crop and Horticultural Science, Wellington, v. 18, n. 2-3, p. 141-145, 1990.

HENRY, Z. A.; SU, B.; ZHANG, H. Resistance of soya beans to compression. Journal of Agricultural Engineering Research, London, v. 76, n. 2, p. 175-181, 2000.

HERNÁNDEZ, L. N. et al. Caracterización de las propiedades mecânicas de ensayos de compresión utilizando calabaza. In: CONFERENCIA INTERNACIONAL DE INGENIERÍA MECÁNICA, 7., 2012, Santa Clara. Anais... Havana: Feijóo, 2012. p. 68-71.

KROKIDA, M. K.; KARATHANOS, V. T.; MAROULIS, Z. B. Effect of osmotic dehydration on viscoelastic properties of apple and banana. Drying Technology, London, v. 18, n. 1, p. 951-966, 2000.

LEWICKI, P. P.; JAKUBCZYK, E. Effect of hot air temperature on mechanical properties of dried apples. Journal of Food Engineering, Davis, v. 64, n. 2, p. 307314, 2004.

LEE, H. J. et al. Bruising injury of persimmon (Diospyros kaki cv. Fuyu) fruits. Scientia Horticulturae, Mission, v. 103, n. 3, p. 179-185, 2005.

LI, Y. et al. Physical properties effect on stress-strain behavior of wheat en masse: part I. Load response dependence on initial bulk density in moisture content. Transactions of the ASAE, San Joseph, v. 32, n. 3, p. 194202, 1989.

MAROCO, J. Análise estatística com utilização do SPSS. Lisboa: Sílabo, 2003. 
MAYOR, L.; CUNHA, R. L.; SERENO, A. M. Relation between mechanical properties and structural changes during osmotic dehydration of pumpkin. Food Research International, Amsterdam, v. 40, n. 3, p. 448-460, 2007.

MOHSENIN, N. N. Physical properties of plant and animal materials. New York: Gordon and Breach Publishers, 1986.

NEVES, L. C. Manual pós-colheita da fruticultura brasileira. Londrina: Eduel, 2009.

PLA, M. F. E. et al. Pumpkin (Cucurbita moschata Duchesne ex Poiret) mesocarp tissue as a food matrix for supplying in a food product. Journal of Food Engineering, Davis, v. 92, n. 3, p. 361-369, 2009.

RESENDE, O. et al. Comportamento mecânico dos grãos de feijão submetidos a compressão. Revista Brasileira de Engenharia Agrícola e Ambiental, Campina Grande, v. 11, n. 4, p. 404-409, 2007.

RIBEIRO, D. M. et al. Propriedades mecânicas dos grãos de soja em função do teor de água. Revista de Engenharia Agrícola, Jaboticabal, v. 27, n. 2, p. 493-500, 2007.

ROCHA, R. H. C. et al. Observação dos tecidos internos do melão 'Gália', submetidos a injúrias mecânicas, por meio de tomografia de ressonância magnética nuclear. Revista Brasileira de Armazenamento, Viçosa, v. 36, n. 2, p. 133-137, 2011.

ROYLANCE, D. Introduction to elasticity. Cambridge: MIT, 2000.
SANTOS, J. E. S.; CHITARRA, I. F. C. Relação entre a idade do cacho de banana 'prata' à colheita e a qualidade dos frutos após a colheita. Pesquisa Agropecuária Brasileira, Brasília, DF, v. 33, n. 1, p. 1475-1480, 1998.

SASAKI, F. F. et al. Alterações fisiológicas, qualitativas e microbiológicas durante o armazenamento de abóbora minimamente processada em diferentes tipos de corte. Horticultura Brasileira, Brasília, DF, v. 24, n. 2 p. 170174, 2006.

SILVA, K. S. Desidratação de abóbora (Cucurbita moschata) por métodos combinados. 2009. $92 \mathrm{f}$. Dissertação (Mestrado em Engenharia de Alimentos) Universidade Estadual Paulista, São José do Rio Preto, 2009.

TASCÓN, C. E. O.; RESTREPO, E. C. M.; AYALA, A. A. Efecto de la broca del café em la firmeza del grano em los estados de cereja, pergamino húmedo y pergamino seco. Cenicafe, Bogotá, v. 53, n. 3, p. 25-33, 2002.

TELIS, V. R. N.; ROMERO, J. T.; GABAS, A. L. Solids rheology for dehydrated food and biological materials. Drying Technology, London, v. 23, n. 4, p. 759-780, 2005.

YAM-TZEC, J. A. et al. Comportamiento de los frutos de guayaba (Psidium guajava L.) sometidos a impacto. Revista Ciencias Técnicas Agropecuarias, La Habana, v. 20, n. 2, p. 57-61, 2011. 